\title{
$\mathrm{Pt} / \mathrm{CeO}_{2}-\mathrm{ZrO}_{2}-\mathrm{La}_{2} \mathrm{O}_{3}$ 柴油车尾气氧化催化剂活性及抗硫性能
}

\author{
钟富兰, 钟喻娇, 肖益鸿, 蔡国辉, 郑勇, 魏可镁 ${ }^{*}$ \\ 福州大学化肥催化剂国家工程研究中心, 福建福州 350002
}

\begin{abstract}
摘要: 采用两种方法制备了三种 $\mathrm{Pt} / \mathrm{CeO}_{2}-\mathrm{ZrO}_{2}-\mathrm{La}_{2} \mathrm{O}_{3}$ 柴油车尾气氧化催化剂, 并用 $\mathrm{X}$ 射线衍射、 $\mathrm{N}_{2}$ 物理吸附、程序升温还原、 程序升温脱附、X 射线苂光光谱和红外光谱等方法对其进行了表征. 结果发现,制备方法对催化剂的结构、织构、抗硫性能及 催化性能的影响非常大. 对其进行硫中毒, 导致起燃温度明显升高. 将 $\mathrm{ZrO}_{2}$ 和 $\mathrm{La}_{2} \mathrm{O}_{3}$ 沉积在 $\mathrm{CeO}_{2}$ 表面所制得的 $\mathrm{Pt} / \mathrm{CeO}_{2}-\mathrm{ZrO}_{2}-\mathrm{La}_{2} \mathrm{O}_{3}$ 催化剂表现出更高的抗硫及催化氧化性能, 这主要归功于 $\mathrm{Pt}$ 在富 $\mathrm{Zr}$ 载体表面具有更高的分散性.

关键词: 氧化铈; 氧化锆; 氧化镧; 铂; 沉积沉淀; 硫中毒; 柴油车尾气净化

中图分类号: 0643 文献标识码: A
\end{abstract}

收稿日期: 2011-04-18. 接受日期: 2011-06-03.

*通讯联系人. 电话/传真: (0591)83770818; 电子信箱: wei-kemei@163.com

基金来源：国家科技支撑计划 (2007BAE08B01).

本文的英文电子版(国际版)由Elsevier出版社在ScienceDirect上出版(http://www.sciencedirect.com/science/journal/18722067).

\section{Sulfur Resistance and Activity of $\mathrm{Pt} / \mathrm{CeO}_{2}-\mathrm{ZrO}_{2}-\mathrm{La}_{2} \mathrm{O}_{3}$ Diesel Oxidation Catalysts}

\author{
ZHONG Fulan, ZHONG Yujiao, XIAO Yihong, CAI Guohui, ZHENG Yong, WEI Kemei* \\ National Engineering Research Center of Chemical Fertilizer Catalyst, Fuzhou University, Fuzhou 350002, Fujian, China
}

\begin{abstract}
Three $\mathrm{Pt} / \mathrm{CeO}_{2}-\mathrm{ZrO}_{2}-\mathrm{La}_{2} \mathrm{O}_{3}$ diesel oxidation catalysts were prepared by two different routes and characterized by X-ray diffraction, $\mathrm{N}_{2}$ adsorption, temperature-programmed reduction, temperature-programmed desorption, X-ray photoelectron spectroscopy, and infrared spectroscopy. The synthesis procedure affected the structure, texture, sulfur resistance, and catalytic activity of the catalysts. Sulfur poisoning increased the light-off temperature of all the catalysts, but the $\mathrm{Pt} / \mathrm{CeO}_{2}-\mathrm{ZrO}_{2}-\mathrm{La}_{2} \mathrm{O}_{3}$ catalyst prepared by depositing $\mathrm{ZrO}_{2}$ and $\mathrm{La}_{2} \mathrm{O}_{3}$ on the surface of $\mathrm{CeO}_{2}$ nanoparticles exhibited better sulfur tolerance and catalytic activity with simulated diesel emission due to the high dispersion of $\mathrm{Pt}$ on $\mathrm{CeO}_{2}-\mathrm{ZrO}_{2}-\mathrm{La}_{2} \mathrm{O}_{3}$ oxide with a $\mathrm{Zr}$-rich surface.
\end{abstract}

Key words: ceria; zirconia; lanthana; platinum; deposition-precipitation; sulfur-poisoning; diesel exhaust purification

Received 18 April 2011. Accepted 3 June 2011.

*Corresponding author.Tel/Fax: +86-591-83770818; E-mail:wei-kemei@163.com

This work was supported by the National Key Technology R\&D Program (2007BAE08B01).

English edition available online at Elsevier ScienceDirect (http://www.sciencedirect.com/science/journal/18722067).

Diesel engines are widely used in automotive vehicles because of their high fuel efficiency and low $\mathrm{NO}_{x}$ production as compared to gasoline engines [1]. The lean combustion of diesel engine contributes to good fuel economy, but it also results in a low emission temperature. This is bad for the elimination of diesel pollutant gases, which are mainly carbon monoxide, hydrocarbons, and particulate matter (PM) that contains elemental carbon (ca. 31\%), sulphates and moisture (ca. 14\%), unburnt fuel (ca. 7\%), lubricant oil (ca. 40\%), and metals [2]. Among several post-treatment technologies used for diesel exhaust gases, catalytic oxidation by diesel oxidation catalysts (DOCs) working in excess oxygen is a promising solution [3-6]. However, many studies [7-9] have shown that although both Pd and Pt-based DOCs exhibit high initial activity, they are easily deactivated. Sulfur or impurity poisoning of the catalysts has been proposed in previous studies [10-13]. Therefore, improving the sulfur tolerance of DOCs is of great concern. 
The choice of the support is important for preparing highly efficient and sulfur-tolerant DOCs. Compared to inert catalyst supports such as $\mathrm{Al}_{2} \mathrm{O}_{3}$ and $\mathrm{SiO}_{2}$, ceria-based materials can create "active oxygen" [14], and thus reduce the light-off temperature of contaminant oxidation over DOCs. A large number of studies have shown that the use of $\mathrm{CeO}_{2}$-based materials as the support for Pt-based DOCs accelerated the oxidation rate of diesel soot due to the high availability of surface oxygen and high surface reducibility $[10,15,16]$, but these catalysts were easily sulfated during the removal of the pollutants in diesel exhaust gas since $\mathrm{SO}_{2}$ was present and blocked active sites. Bazin et al. [17] reported that the addition of zirconia to ceria limited sulfiding in the bulk of the oxide, and thereby reduced the total sulfur uptake. Rohart et al. [18] also reported that the quantity of sulfate adsorption on ceria-rich oxide was more than on zirconia-rich oxides as a result of strong surface basicity. This suggested that the sulfur resistance of $\mathrm{CeO}_{2}-\mathrm{ZrO}_{2}$ materials can be tuned by modifying the surface composition.

It is well-known that the preparation method and the $\mathrm{CeO}_{2}$ component of $\mathrm{CeO}_{2}-\mathrm{ZrO}_{2}$ materials can give different crystalline phases including three stable phases (monoclinic $(m)$, tetragonal $(t)$, cubic $(c))$, and two metastable phases $\left(t^{\prime}\right.$, $\left.t^{\prime \prime}\right)[10,19]$, and also give significant differences in thermal, chemical, and redox properties. Our previous study [20] showed that the incorporation of $\mathrm{La}_{2} \mathrm{O}_{3}$ into $\mathrm{CeO}_{2}-\mathrm{ZrO}_{2}$ oxide can effectively improve its thermal and chemical properties, which are key parameters that determine the potential application of $\mathrm{CeO}_{2}-\mathrm{ZrO}_{2}$ materials in the removal of pollutants in exhaust gases from vehicles. In the present work, thermally stable $\mathrm{CeO}_{2}-\mathrm{ZrO}_{2}-\mathrm{La}_{2} \mathrm{O}_{3}$ ternary oxides were first prepared using two frequently used synthesis routes for fabricating heterogeneous catalysts, that is, deposition-precipitation and co-precipitation methods. These were used as the support of Pt-based DOCs for the simultaneous oxidation of $\mathrm{CO}$ and $\mathrm{C}_{3} \mathrm{H}_{6}$. The structure, texture, and surface properties of the catalysts were characterized in detail by X-ray diffraction (XRD), $\mathrm{N}_{2}$ adsorption, temperature-programmed reduction (TPR), temperature-programmed desorption (TPD), X-ray photoelectron spectroscopy (XPS), and infrared (IR) spectroscopy. The emphasis was on the comparison of the sulfur resistance of the catalysts prepared by the two methods in order to develop practical $\mathrm{CeO}_{2}-\mathrm{ZrO}_{2}$-based DOCs with a low light-off temperature.

\section{Experimental}

\subsection{Catalyst preparation}

The $\mathrm{CeO}_{2}-\mathrm{ZrO}_{2}-\mathrm{La}_{2} \mathrm{O}_{3}$ materials were prepared by two methods: deposition-precipitation and co-precipitation. For deposition-precipitation method, the required amount of $\mathrm{Ce}\left(\mathrm{NO}_{3}\right)_{3} \cdot 6 \mathrm{H}_{2} \mathrm{O}$ was first calcined at $573 \mathrm{~K}$ for $4 \mathrm{~h}$ to obtain $\mathrm{CeO}_{2}$ particles with a high surface area. A slurry was obtained by ball-milling the $\mathrm{CeO}_{2}$ with some deionized water for several hours. The required amount of ammonia solution was added into the slurry. A stoichiometric mixture of $\mathrm{ZrOCl}_{2} \cdot 8 \mathrm{H}_{2} \mathrm{O}$ and $\mathrm{La}\left(\mathrm{NO}_{3}\right)_{3} \cdot 6 \mathrm{H}_{2} \mathrm{O}$ solutions $(\mathrm{Ce}: \mathrm{Zr}: \mathrm{La}=$ 5:4:1, molar ratio) was used to deposit the $\mathrm{CeO}_{2}$ particles. The $\mathrm{pH}$ of solution was controlled at 9.0. The resulting precipitates were filtered, washed with distilled water, dried, and calcined at $873 \mathrm{~K}$ for $4 \mathrm{~h}$ in air. The resulting $\mathrm{CeO}_{2}-\mathrm{ZrO}_{2}-\mathrm{La}_{2} \mathrm{O}_{3}$ was denoted as $\mathrm{A}$.

After ball-milling the $\mathrm{ZrO}_{2}$ particles with an amount of deionized water for several hours, the required amount of ammonia solution was added into the slurry. A stoichiometric mixture of $\mathrm{Ce}\left(\mathrm{NO}_{3}\right)_{3} \cdot 6 \mathrm{H}_{2} \mathrm{O}$ and $\mathrm{La}\left(\mathrm{NO}_{3}\right)_{3} \cdot 6 \mathrm{H}_{2} \mathrm{O}$ solutions was used to deposit the milled $\mathrm{ZrO}_{2}$ particles. The $\mathrm{pH}$ of solution was controlled at 9.0. The resulting precipitates were filtered, washed with distilled water, dried, and calcined at $873 \mathrm{~K}$ for $4 \mathrm{~h}$ in air. The $\mathrm{CeO}_{2}-\mathrm{ZrO}_{2}-\mathrm{La}_{2} \mathrm{O}_{3}$ oxide obtained with the same composition as A was denoted as $\mathrm{B}$. The $\mathrm{ZrO}_{2}$ particles were prepared by precipitation with ammonia from a solution of $\mathrm{ZrOCl}_{2} \cdot 8 \mathrm{H}_{2} \mathrm{O}$, which was followed by washing, drying at $383 \mathrm{~K}$ for $15 \mathrm{~h}$, and calcination at $823 \mathrm{~K}$ for $4 \mathrm{~h}$.

For co-precipitation method, the mixed aqueous solution of $\mathrm{Ce}\left(\mathrm{NO}_{3}\right)_{3} \cdot 6 \mathrm{H}_{2} \mathrm{O}, \mathrm{ZrOCl}_{2} \cdot 8 \mathrm{H}_{2} \mathrm{O}$, and $\mathrm{La}\left(\mathrm{NO}_{3}\right)_{3} \cdot 6 \mathrm{H}_{2} \mathrm{O}$ was quickly dropped into ammonia solution and the $\mathrm{pH}$ of solution was controlled at 9.0. The precipitate obtained was filtered, washed with distilled water, dried, and calcined at $873 \mathrm{~K}$ in air. The resulting $\mathrm{CeO}_{2}-\mathrm{ZrO}_{2}-\mathrm{La}_{2} \mathrm{O}_{3}$ oxide was denoted as $\mathrm{C}$ (with the same molar composition as $\mathrm{A}$ and B).

The loading of platinum on the $\mathrm{CeO}_{2}-\mathrm{ZrO}_{2}-\mathrm{La}_{2} \mathrm{O}_{3}$ oxides was carried out by impregnation using a solution of $\mathrm{H}_{2} \mathrm{PtCl}_{6} \cdot 6 \mathrm{H}_{2} \mathrm{O}$. The resultant solids were calcined at $873 \mathrm{~K}$ for $4 \mathrm{~h}$ in air. The catalysts obtained were marked as $\mathrm{Pt} / \mathrm{A}$, $\mathrm{Pt} / \mathrm{B}$, and Pt/C. The Pt/A-S, Pt/B-S, and Pt/C-S denoted the sulfated catalysts. The Pt/A-R, Pt/B-R, and Pt/C-R denoted the regenerated catalysts. The loading of platinum was determined by a Axios Petro X-Ray fluorescence (XRF) spectrometer.

For comparison, the $\mathrm{Pt} / \mathrm{Al}_{2} \mathrm{O}_{3}$ catalyst was also prepared. $\mathrm{Al}_{2} \mathrm{O}_{3}$ was obtained by precipitation with the required amount of ammonia and $\mathrm{NH}_{4} \mathrm{HCO}_{3}$ from a solution of $\mathrm{Al}\left(\mathrm{NO}_{3}\right)_{3} \cdot 9 \mathrm{H}_{2} \mathrm{O}$, followed by washing, drying for $15 \mathrm{~h}$ at $383 \mathrm{~K}$, and calcination at $873 \mathrm{~K}$ for $4 \mathrm{~h}$.

\subsection{Catalyst characterization}

XRD data were recorded on a Panalytical X'Pert Pro diffractometer at $40 \mathrm{kV}$ and $40 \mathrm{~mA}$ with a step of $0.0167^{\circ}$ at a 
scanning rate of $10 \%$ min using Co $K_{\alpha}$ radiation, which was then revised to $\mathrm{Cu} K_{\alpha}$. The specific surface areas and pore size distribution of the samples were determined on a TriStar 3000 apparatus by $\mathrm{N}_{2}$ adsorption at $77 \mathrm{~K}$. The samples were outgassed in vacuum at $300{ }^{\circ} \mathrm{C}$ for more than $3 \mathrm{~h}$ until the residual pressure was less than $1333 \mathrm{~Pa}$ before the adsorption. XPS spectra were collected on a VG ESCALAB 250 XPS system with a monochromatized $\mathrm{Al} K_{\alpha}$ X-ray source $(15 \mathrm{kV}, 200 \mathrm{~W}, 500 \mu \mathrm{m}$, pass energy $=20 \mathrm{eV})$. All binding energies were calibrated using the $\mathrm{C} 1 \mathrm{~s}$ peak at $284.6 \mathrm{eV}$.

The CO-TPD experiments were performed on an AutoChem 2920 instrument by the pulse technique. About 100 $\mathrm{mg}$ of samples were placed in a quartz tube and pretreated at $773 \mathrm{~K}$ in flowing $\mathrm{H}_{2}$ for $30 \mathrm{~min}$, then in flowing $\mathrm{He}$ for 20 min, and subsequently cooled to room temperature in He. The reduced samples were pulsed with $\mathrm{CO}$ at an interval of 3 min until the intensity of the peak was constant. The temperature of the sample was then raised from room temperature to $1123 \mathrm{~K}$ at a rate of $10 \mathrm{~K} / \mathrm{min}$. The metal dispersion was determined by the amount of $\mathrm{CO}$ consumed during the pulse.

The desulfiding characteristics were analyzed with a quardrupole mass spectrometer (Ametek Process Instruments, Model Dycor DM100M). The powder samples were sulfated by exposure to a feed containing $0.04 \% \mathrm{SO}_{2}, 13 \%$ $\mathrm{O}_{2}$, and balance $\mathrm{He}$ (feed rate of $200 \mathrm{ml} / \mathrm{min}$ ) for $30 \mathrm{~min}$ at $623 \mathrm{~K}$. The catalysts were then subjected to desulfiding under $10 \% \mathrm{H}_{2}-90 \% \mathrm{He}$ by raising the temperature from 563 to $873 \mathrm{~K}$ at a rate of $3 \mathrm{~K} / \mathrm{min}$.

\subsection{Activity test}

Catalytic activity tests for the oxidation of $\mathrm{CO}$ and $\mathrm{C}_{3} \mathrm{H}_{6}$ were carried out on a fixed-bed continuous flow reactor. The catalyst $(0.1 \mathrm{~g})$ was held in a quartz glass tube reactor (i.d. $10.5 \mathrm{~mm}$ ) equipped with a temperature-programmed controller. Prior to measurement, the catalyst was pretreated in $1 \% \mathrm{CO}-99 \% \mathrm{He}$ at $673 \mathrm{~K}$ for $0.5 \mathrm{~h}$. For the sulfated sample, the powder samples were sulfated by exposure to a feed containing $0.04 \% \mathrm{SO}_{2}, 13 \% \mathrm{O}_{2}$, and balance $\mathrm{He}$ (feed rate of $200 \mathrm{ml} / \mathrm{min}$ ) for $30 \mathrm{~min}$ at $623 \mathrm{~K}$. The amount of $\mathrm{SO}_{2}$ adsorbed was determined by XRF. The sulfated samples were regenerated in situ in a $\mathrm{H}_{2}$ atmosphere at $823 \mathrm{~K}$ for 1 h. The reaction gas was a mixture of $0.1 \% \mathrm{CO}, 0.01 \% \mathrm{C}_{3} \mathrm{H}_{6}$, $13.5 \% \mathrm{O}_{2}$, and balance He. The total flow rate of the reaction gas was $200 \mathrm{ml} / \mathrm{min}\left(\mathrm{GHSV}=170000 \mathrm{~h}^{-1}\right)$. The catalytic activity was measured while the temperature was raised from 343 to $513 \mathrm{~K}$ at a rate of $10 \mathrm{~K} / \mathrm{min}$. $\mathrm{CO}$ and $\mathrm{C}_{3} \mathrm{H}_{6}$ compositions in the gas were monitored by two gas chromatographs, GC-14C and 9750, equipped with a thermal conduction detector (TCD) and flame ionization detec- tor (FID), respectively.

$$
\begin{aligned}
& \mathrm{CO} \text { conversion }=\left(C_{\mathrm{CO} \text {, inlet }}-C_{\mathrm{CO} \text {, outlet }}\right) / \mathrm{C}_{\mathrm{CO}, \text { inlet }} \\
& \mathrm{C}_{3} \mathrm{H}_{6} \text { conversion }=\left(\mathrm{C}_{\mathrm{C} 3 \mathrm{H} 6 \text {, inlet }}-\mathrm{C}_{\mathrm{C} 3 \mathrm{H} 6 \text {, outlet }}\right) / \mathrm{C}_{\mathrm{C} 3 \mathrm{H} 6 \text {, inlet }}
\end{aligned}
$$
where $C_{i \text {, inlet }}$ is the concentration of compound $\mathrm{i}$ at the reactor inlet and $C_{i \text {, outlet }}$ is that at the reactor outlet.

\section{Results and discussion}

\subsection{Structure and texture of $\mathrm{Pt} / \mathrm{CeO}_{2}-\mathrm{ZrO}_{2}-\mathrm{La}_{2} \mathrm{O}_{3}$ samples before and after sulfur treatment}

Figure 1 displays the XRD patterns of the $\mathrm{Pt} / \mathrm{A}, \mathrm{Pt} / \mathrm{B}$, $\mathrm{Pt} / \mathrm{C}, \mathrm{Pt} / \mathrm{A}-\mathrm{S}, \mathrm{Pt} / \mathrm{B}-\mathrm{S}$, and $\mathrm{Pt} / \mathrm{C}-\mathrm{S}$ samples. All samples did not show any Bragg diffractive peak of metal Pt or Pt oxide. This was because the loading of $\mathrm{Pt}(0.5 \mathrm{wt} \%$ in Table 1$)$ was too low. For the $\mathrm{Pt} / \mathrm{A}$ sample prepared by the deposition of $\mathrm{ZrO}_{2}$ and $\mathrm{La}_{2} \mathrm{O}_{3}$ on $\mathrm{CeO}_{2}$ nanoparticles, all the Bragg diffractive peaks were indexed to a mixed tetragonal (JCPDS 38-1436) and cubic (JCPDS 38-1439) phase. Peaks of lanthana and zirconia oxides were not seen, suggesting that $\mathrm{La}$ and $\mathrm{Zr}$ cations were either incorporated into the ceria lattice or were well dispersed on the ceria surface in the form of amorphous lanthana and zirconia oxides. For the $\mathrm{Pt} / \mathrm{B}$ sample prepared by the deposition of $\mathrm{CeO}_{2}$ and $\mathrm{La}_{2} \mathrm{O}_{3}$ on $\mathrm{ZrO}_{2}$ nanoparticles, the main diffraction peaks were indexed as the cubic phase. Some weak impurity peaks indexed as the monoclinic phase of $\mathrm{ZrO}_{2}$ was detected, indicating that $\mathrm{ZrO}_{2}$ was not fully incorporated into the $\mathrm{CeO}_{2}$ lattice after calcination at $873 \mathrm{~K}$. A fraction of the $\mathrm{ZrO}_{2}$ existed as a separated monoclinic phase. These results suggested that the $\mathrm{CeO}_{2}-\mathrm{ZrO}_{2}-\mathrm{La}_{2} \mathrm{O}_{3}$ supports prepared by the deposition-precipitation method were composed of mixed phases, which depended on the deposition procedure. However, the $\mathrm{Pt} / \mathrm{C}$ sample prepared by co-precipitation had a single cubic fluorite structure, as indicated by the XRD pattern that was very close to that of $\mathrm{CeO}_{2}$. Moreover, the lattice parameter

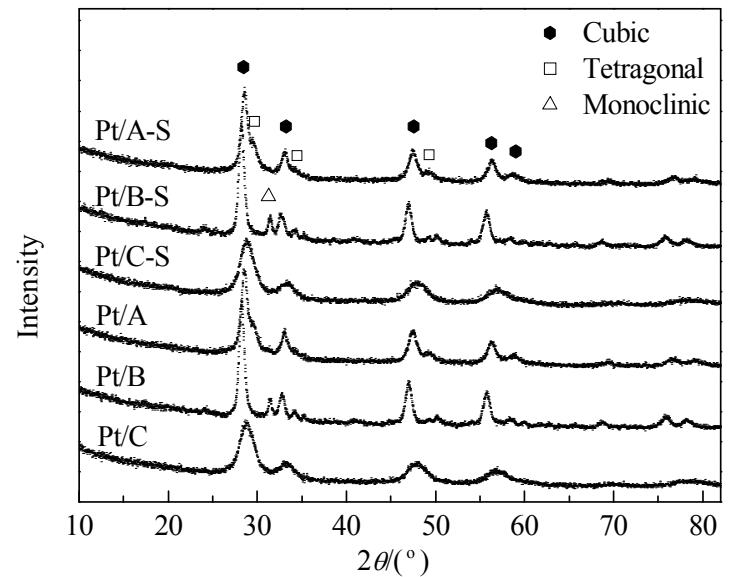

Fig. 1. XRD patterns of the non-sulfated and sulfated $\mathrm{Pt} / \mathrm{CeO}_{2}$ $\mathrm{ZrO}_{2}-\mathrm{La}_{2} \mathrm{O}_{3}$ catalysts. 
Table 1 Physiochemical properties of the $\mathrm{Pt} / \mathrm{CeO}_{2}-\mathrm{ZrO}_{2}-\mathrm{La}_{2} \mathrm{O}_{3}$ and $\mathrm{Pt} / \mathrm{Al}_{2} \mathrm{O}_{3}$ catalysts before and after sulfiding

\begin{tabular}{|c|c|c|c|c|c|c|c|}
\hline Sample & $A_{\mathrm{BET}} /\left(\mathrm{m}^{2} / \mathrm{g}\right)$ & $\begin{array}{c}\text { Pore Size } \\
(\mathrm{nm})\end{array}$ & $\begin{array}{l}\text { Pore Volume } \\
\left(\mathrm{cm}^{3} / \mathrm{g}\right)\end{array}$ & $\begin{array}{c}\text { Pt content }{ }^{\mathrm{a}} \\
(\mathrm{wt} \%)\end{array}$ & $\begin{array}{c}\mathrm{SO}_{2} \text { content }^{\mathrm{a}} \\
(\mathrm{wt} \%)\end{array}$ & $\begin{array}{c}\text { Metal dispersion } \\
(\%) \\
\end{array}$ & $a^{\mathrm{b}} / \mathrm{nm}$ \\
\hline $\mathrm{Pt} / \mathrm{A}$ & 45.4 & 5.32 & 0.139 & 0.56 & - & 96.45 & 0.542 \\
\hline $\mathrm{Pt} / \mathrm{B}$ & 49.6 & 6.46 & 0.191 & 0.53 & - & 82.51 & 0.546 \\
\hline $\mathrm{Pt} / \mathrm{C}$ & 67.8 & 1.85 & 0.077 & 0.52 & - & 78.97 & 0.535 \\
\hline $\mathrm{Pt} / \mathrm{A}-\mathrm{S}$ & 20.9 & 6.26 & 0.099 & 0.51 & 0.95 & 6.97 & 0.541 \\
\hline $\mathrm{Pt} / \mathrm{B}-\mathrm{S}$ & 26.3 & 6.81 & 0.145 & 0.53 & 1.48 & 4.20 & 0.547 \\
\hline $\mathrm{Pt} / \mathrm{C}-\mathrm{S}$ & 34.1 & 1.71 & 0.042 & 0.48 & 1.10 & 4.08 & 0.529 \\
\hline $\mathrm{Pt} / \mathrm{Al}_{2} \mathrm{O}_{3}$ & 198.4 & 4.22 & 0.563 & 0.50 & - & 65.89 & - \\
\hline $\mathrm{Pt} / \mathrm{Al}_{2} \mathrm{O}_{3}-\mathrm{S}$ & 194.2 & 4.19 & 0.530 & 0.49 & 0.94 & 35.67 & - \\
\hline $\mathrm{Pt} / \mathrm{A}-\mathrm{R}$ & - & - & - & - & - & 7.92 & - \\
\hline $\mathrm{Pt} / \mathrm{B}-\mathrm{R}$ & - & - & - & - & - & 5.02 & - \\
\hline $\mathrm{Pt} / \mathrm{C}-\mathrm{R}$ & - & - & - & - & - & 4.97 & - \\
\hline $\mathrm{Pt} / \mathrm{Al}_{2} \mathrm{O}_{3}-\mathrm{R}$ & - & - & - & - & - & 34.30 & - \\
\hline
\end{tabular}

${ }^{\mathrm{a}}$ Determined by XRF.

${ }^{\mathrm{b} C a l c u l a t e d}$ according to the (111) facets of the cubic phase.

(a) value for the $\mathrm{Pt} / \mathrm{B}$ sample was significantly increased by the doping of $\mathrm{La}^{3+}$ (ionic radius of $\mathrm{La}^{3+}=0.116 \mathrm{~nm}$ ) [21], while the lattice parameter $(a)$ value of the $\mathrm{Pt} / \mathrm{A}$ sample was comparable with that of $\mathrm{CeO}_{2}$ (ca. $0.540 \mathrm{~nm}$ ), suggesting that considerable amounts of $\mathrm{Zr}^{4+}$ (ionic radius of $\mathrm{Zr}^{4+}=$ $0.084 \mathrm{~nm}$ ) [19] were doped into the $\mathrm{CeO}_{2}$ fluorite lattice in the case of the Pt/A sample. This caused a drastic difference in the surface atomic composition, which was confirmed by XPS results discussed below.

After sulfur treatment, we did not observe any modifications of the XRD patterns for the Pt/A-S, Pt/B-S, and Pt/C-S samples. This indicated that the sulfiding did not alter their crystalline structure. This was possibly because the pretreatment time was relatively short, such that the sulfate accumulated was below the detection limit, or the sulfate formed was well dispersed on the catalyst surface. However, the sulfiding significantly changed the texture of the samples, as shown by $\mathrm{N}_{2}$ adsorption-desorption measurements (Table 1). The BET surface area and pore volume of the sulfated samples decreased by $50 \%$ and $30 \%$, respectively, implying the bonding of $\mathrm{SO}_{2}$ on the surface of the $\mathrm{CeO}_{2}-\mathrm{ZrO}_{2}-\mathrm{La}_{2} \mathrm{O}_{3}$ support. It is interesting to note that the texture of the reference catalyst $\left(\mathrm{Pt} / \mathrm{Al}_{2} \mathrm{O}_{3}\right)$ was not altered by sulfur poisoning due to the high $\mathrm{SO}_{2}$ adsorption capacity [22]. In addition, the physicochemical properties of $\mathrm{Al}_{2} \mathrm{O}_{3}$ were also completely different from those of the $\mathrm{CeO}_{2}$-based oxide. The $\mathrm{CeO}_{2}$-based oxide was alkaline and exhibited the unique feature of the storage and release of oxygen, which helped the adsorption and oxidation of $\mathrm{SO}_{2}$, thus changing the structure. The XRF results showed that the amount of sulfur adsorbed on the Pt/A-S sample was comparable to that on $\mathrm{Pt} / \mathrm{Al}_{2} \mathrm{O}_{3}-\mathrm{S}$, and lower than those of the Pt/B-S and Pt/C-S samples. This indicated that the Pt/A sample had better sulfur resistance.

\subsection{Catalytic activity of the $\mathrm{Pt} / \mathrm{CeO}_{2}-\mathrm{ZrO}_{2}-\mathrm{La}_{2} \mathrm{O}_{3}$ samples}

Figure 2 shows the conversion curves of $\mathrm{CO}$ and $\mathrm{C}_{3} \mathrm{H}_{6}$ over the $\mathrm{Pt} / \mathrm{A}, \mathrm{Pt} / \mathrm{B}, \mathrm{Pt} / \mathrm{C}$, and $\mathrm{Pt} / \mathrm{Al}_{2} \mathrm{O}_{3}$ before and after sulfur treatment. The $\mathrm{Pt} / \mathrm{A}$ catalyst exhibited the best activities for both $\mathrm{CO}$ and $\mathrm{C}_{3} \mathrm{H}_{6}$ oxidation among the catalysts investigated. It gave values of $T_{50}(384 \mathrm{~K}$ for $\mathrm{CO}$ conversion and $403 \mathrm{~K}$ for $\mathrm{C}_{3} \mathrm{H}_{6}$ oxidation), which were lower than those from the $\mathrm{Pt} / \mathrm{B}(407 \mathrm{~K}$ for $\mathrm{CO}$ conversion and $416 \mathrm{~K}$ for $\mathrm{C}_{3} \mathrm{H}_{6}$ oxidation) and the $\mathrm{Pt} / \mathrm{C}(398 \mathrm{~K}$ for $\mathrm{CO}$ conversion and $417 \mathrm{~K}$ for $\mathrm{C}_{3} \mathrm{H}_{6}$ oxidation) catalysts. Overall, the non-sulfated $\mathrm{Pt} / \mathrm{A}$ was better in oxidation catalytic activity as compared with the commercial $\mathrm{Pt} / \mathrm{Al}_{2} \mathrm{O}_{3}$ sample $(394 \mathrm{~K}$ for $\mathrm{CO}$ conversion and $403 \mathrm{~K}$ for $\mathrm{C}_{3} \mathrm{H}_{6}$ oxidation). After sulfur treatment, the light-off temperatures of $\mathrm{CO}$ and $\mathrm{C}_{3} \mathrm{H}_{6}$ oxidation over all the $\mathrm{Pt} / \mathrm{CeO}_{2}-\mathrm{ZrO}_{2}-\mathrm{La}_{2} \mathrm{O}_{3}$ catalysts were increased significantly, while the Pt/A-S catalyst still exhibited a low light-off temperature ( $423 \mathrm{~K}$ for $\mathrm{CO}$ conversion and $433 \mathrm{~K}$ for $\mathrm{C}_{3} \mathrm{H}_{6}$ oxidation) comparable to that of $\mathrm{Pt} / \mathrm{Al}_{2} \mathrm{O}_{3}-\mathrm{S}$ (423 $\mathrm{K}$ for both $\mathrm{CO}$ and $\mathrm{C}_{3} \mathrm{H}_{6}$ oxidation), and significantly lower than those over the $\mathrm{Pt} / \mathrm{B}-\mathrm{S}$ (444 K for $\mathrm{CO}$ conversion and $465 \mathrm{~K}$ for $\mathrm{C}_{3} \mathrm{H}_{6}$ oxidation) and $\mathrm{Pt} / \mathrm{C}-\mathrm{S}$ (487 $\mathrm{K}$ for $\mathrm{CO}$ and $\mathrm{C}_{3} \mathrm{H}_{6}$ oxidations) catalysts. The differences $\left(\Delta T_{50}\right)$ of the $50 \% \mathrm{CO}$ conversion temperature for the $\mathrm{Pt} / \mathrm{Al}_{2} \mathrm{O}_{3}, \mathrm{Pt} / \mathrm{A}, \mathrm{Pt} / \mathrm{B}$, and $\mathrm{Pt} / \mathrm{C}$ catalysts after and before sulfiding were calculated, and found to increase in the order of $\mathrm{Pt} / \mathrm{Al}_{2} \mathrm{O}_{3}(41 \mathrm{~K})<\mathrm{Pt} / \mathrm{A}(51 \mathrm{~K})<\mathrm{Pt} / \mathrm{B}(73 \mathrm{~K})<\mathrm{Pt} / \mathrm{C}(100$ $\mathrm{K})$. These results clearly showed that the $\mathrm{Pt} / \mathrm{A}$ catalyst had excellent sulfur resistance and activity as compared to the $\mathrm{Pt} / \mathrm{Al}_{2} \mathrm{O}_{3}$ catalyst.

We also examined the catalytic activities of all the regenerated catalysts obtained by in situ $\mathrm{H}_{2}$ reduction at $823 \mathrm{~K}$. These are shown in Fig. 2(c) and (f). After the sulfided $\mathrm{Pt} / \mathrm{CeO}_{2}-\mathrm{ZrO}_{2}-\mathrm{La}_{2} \mathrm{O}_{3}$ catalysts were regenerated in a $\mathrm{H}_{2}$ atmosphere at $823 \mathrm{~K}$ for $1 \mathrm{~h}$, the activities of the catalysts 


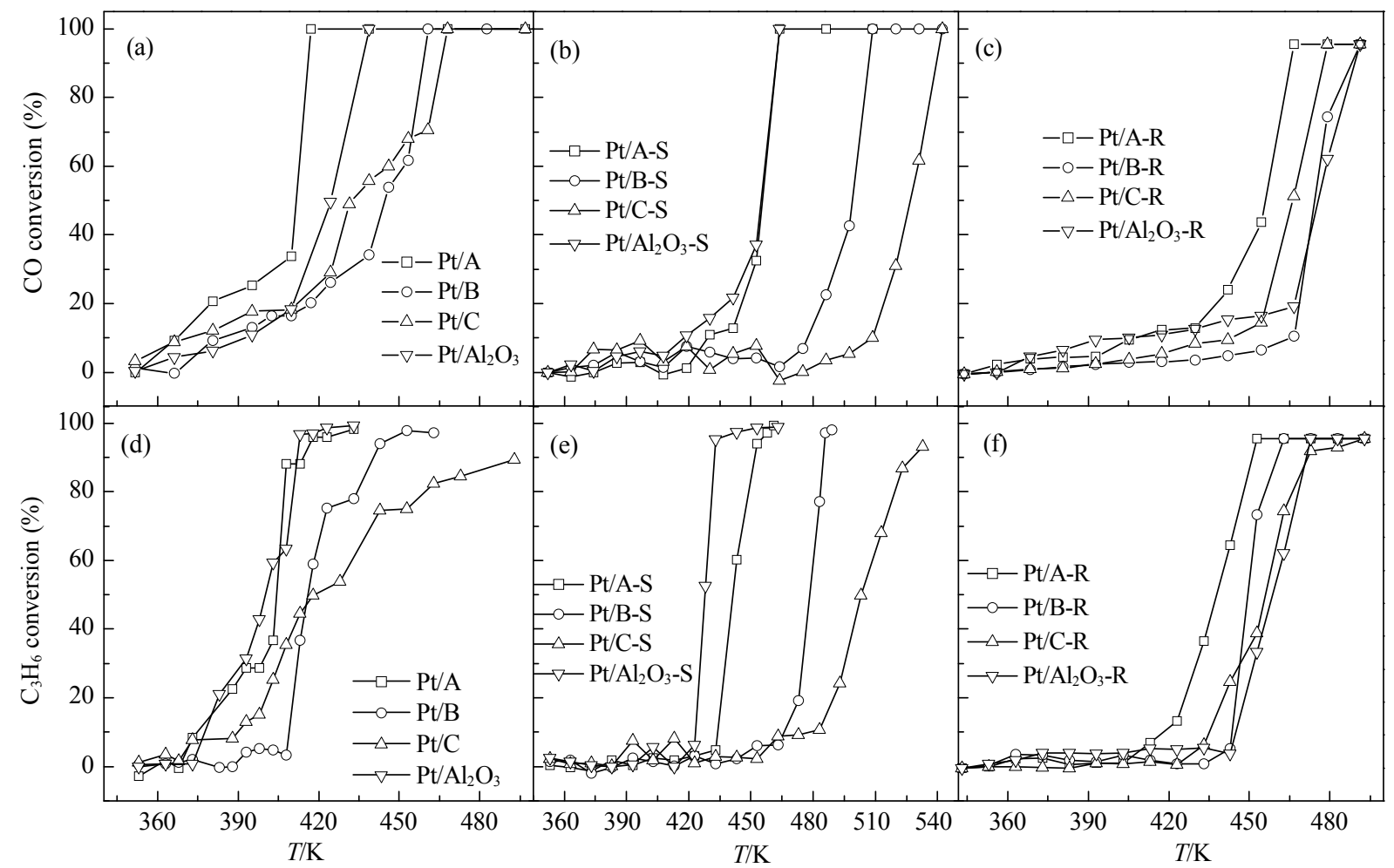

Fig. 2. $\mathrm{CO}$ and $\mathrm{C}_{3} \mathrm{H}_{6}$ conversion over the non-sulfated (a, d), sulfated (b, e), and regenerated (c, f) catalysts.

for both $\mathrm{CO}$ and $\mathrm{C}_{3} \mathrm{H}_{6}$ oxidation were improved. The Pt/A-R catalyst showed a light-off temperature of $423 \mathrm{~K}$ for the oxidation of $\mathrm{CO}$ and $\mathrm{C}_{3} \mathrm{H}_{6}$, which was lower than those of the Pt/B-R $(443 \mathrm{~K})$ and $\mathrm{Pt} / \mathrm{C}-\mathrm{R}(433 \mathrm{~K})$ catalysts. It was interesting to note that the $\mathrm{Pt} / \mathrm{Al}_{2} \mathrm{O}_{3}-\mathrm{R}$ catalyst exhibited poorer activities for the oxidation of $\mathrm{CO}$ and $\mathrm{C}_{3} \mathrm{H}_{6}$ than the $\mathrm{Pt} / \mathrm{Al}_{2} \mathrm{O}_{3}$-S catalyst. Its light-off temperature was instead increased from 423 to $443 \mathrm{~K}$. This may be due to the agglomeration of active $\mathrm{Pt}$ atoms at the high reduction temperature. The $\mathrm{H}_{2}$ reduction at $823 \mathrm{~K}$ did not remove sulfur species bonded to Pt sites. This was confirmed by the TPR-MS results.

\subsection{IR spectroscopy}

To understand the sulfur-poisoning mechanism, we used IR spectroscopy to characterize the sulfated catalysts. It is well-known that $\mathrm{SO}_{2}$ oxidation on ceria gives rise to two types of sulfate: surface and bulk-like species. The former is characterized by IR bands in the $1400-1340 \mathrm{~cm}^{-1}$ range while the latter has a very broad band near $1200 \mathrm{~cm}^{-1}$ $[23,24]$. As seen in Fig. 3, no absorption band in the region of $1700-800 \mathrm{~cm}^{-1}$ was observed for all of the non-sulfated $\mathrm{Pt} / \mathrm{CeO}_{2}-\mathrm{ZrO}_{2}-\mathrm{La}_{2} \mathrm{O}_{3}$ samples. However, after sulfiding, a broad absorption band appeared at $1160 \mathrm{~cm}^{-1}$, indicating that sulfate existed in the form of bulk-like sulfate species. By comparing the intensity of the $1160 \mathrm{~cm}^{-1}$ band, one can find that the amount of bulk sulfate species formed on the $\mathrm{Pt} / \mathrm{A}$ sample was the least of the three catalysts. This was consistent with the catalytic results reported above.

\subsection{XPS analysis}

Figure 4 shows the XPS results on the chemical states of $\mathrm{Pt}$ and $\mathrm{S}$. Table 2 lists the characteristics of the non-sulfated and sulfated $\mathrm{Pt} / \mathrm{CeO}_{2}-\mathrm{ZrO}_{2}-\mathrm{La}_{2} \mathrm{O}_{3}$ catalysts deduced from

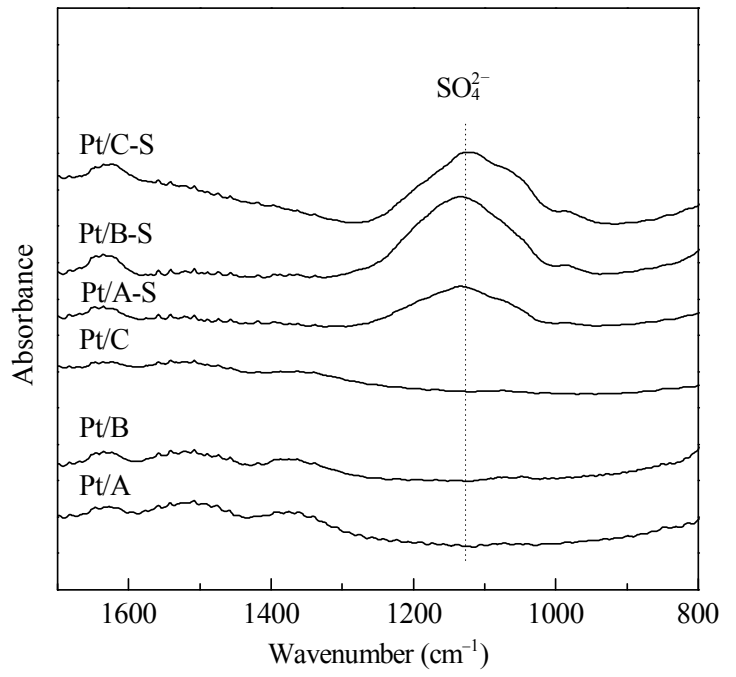

Fig. 3. IR spectra of the $\mathrm{Pt} / \mathrm{CeO}_{2}-\mathrm{ZrO}_{2}-\mathrm{La}_{2} \mathrm{O}_{3}$ catalysts before and after sulfiding. 

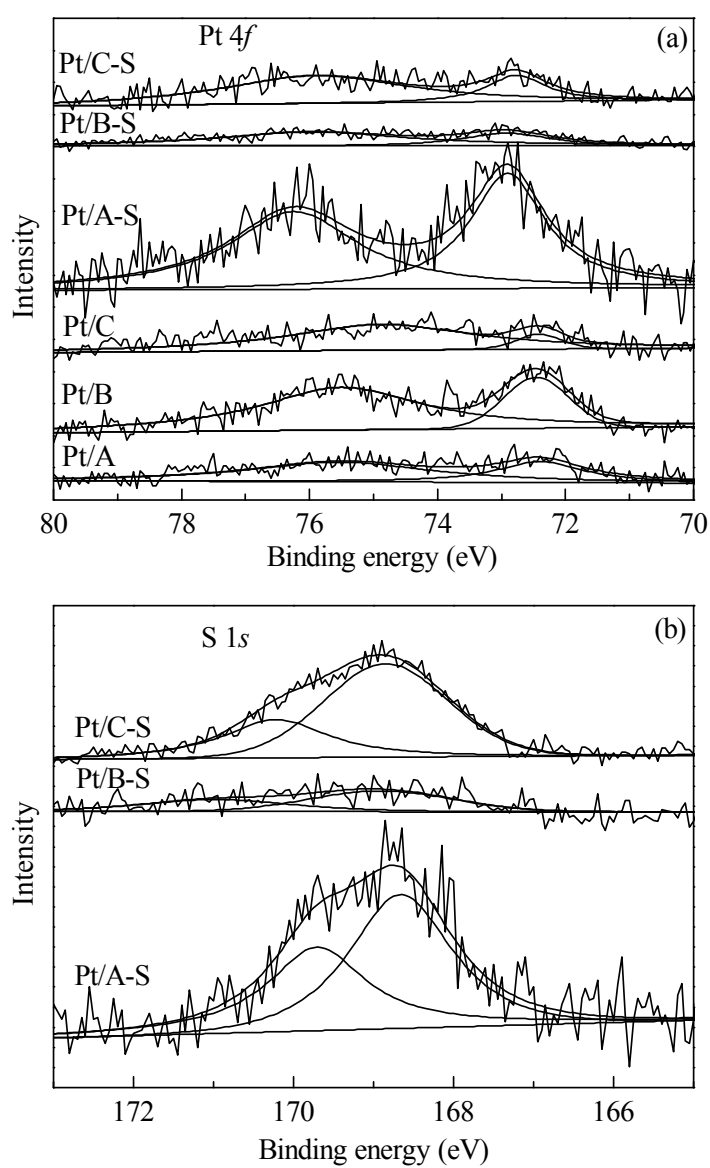

Fig. 4. Pt $4 f$ (a) and $\mathrm{S} 1 s$ (b) XPS profiles of the non-sulfated and sulfated $\mathrm{Pt} / \mathrm{CeO}_{2}-\mathrm{ZrO}_{2}-\mathrm{La}_{2} \mathrm{O}_{3}$ catalysts.

the XPS investigation. There was no difference in the binding energies (BE) of $\mathrm{Ce}, \mathrm{Zr}, \mathrm{La}$, and $\mathrm{O}$ atoms for the $\mathrm{Pt} / \mathrm{A}$, $\mathrm{Pt} / \mathrm{B}$, and $\mathrm{Pt} / \mathrm{C}$ samples. The surface atomic ratio of $\mathrm{Ce}$ to $\mathrm{Zr}$ for the three samples estimated using photoelectron cross-sections calculated by Scofield showed a moderate difference that depended on the synthesis procedure (seen from Table 2). The surface $\mathrm{Ce} / \mathrm{Zr}$ ratio of $\mathrm{Pt} / \mathrm{A}$ was smaller than that of $\mathrm{Pt} / \mathrm{B}$, which was comparable with that of $\mathrm{Pt} / \mathrm{C}$. The Ce/Zr atomic ratios of all samples were lower than their nominal values, and the surface concentration of $\mathrm{Zr}$ was higher than its bulk concentration. This showed that $\mathrm{Ce}, \mathrm{Zr}$, and La were not uniformly distributed in the oxides.
The BE of Pt $4 f$ was between 72.3 to $72.5 \mathrm{eV}$ for the non-sulfated samples, indicating that $\mathrm{Pt}$ existed in the form of PtO [25]. But after sulfur treatment, the $\mathrm{BE}$ of $\mathrm{Pt}^{2+}$ was shifted by $0.5 \mathrm{eV}$ towards higher energy, showing a strong electron withdrawing effect derived from the sulfate species revealed by the $\mathrm{BE}$ of the $\mathrm{S} 2 p_{3 / 2}$ at $168.9 \mathrm{eV}$ [26] and the IR results reported above.

\subsection{TPD and TPR analyses}

Figure 5(a) shows the CO-TPD profiles of the $\mathrm{Pt} / \mathrm{A}, \mathrm{Pt} / \mathrm{B}$, $\mathrm{Pt} / \mathrm{C}, \mathrm{Pt} / \mathrm{A}-\mathrm{S}, \mathrm{Pt} / \mathrm{B}-\mathrm{S}$, and Pt/C-S catalysts. The non-sulfated $\mathrm{Pt} / \mathrm{A}, \mathrm{Pt} / \mathrm{B}$, and $\mathrm{Pt} / \mathrm{C}$ catalysts showed two broad peaks at $400-800$ and $800-1050 \mathrm{~K}$. The intensity of the first desorption peak decreased in the order of $\mathrm{Pt} / \mathrm{A}>\mathrm{Pt} / \mathrm{B}>\mathrm{Pt} / \mathrm{C}$,

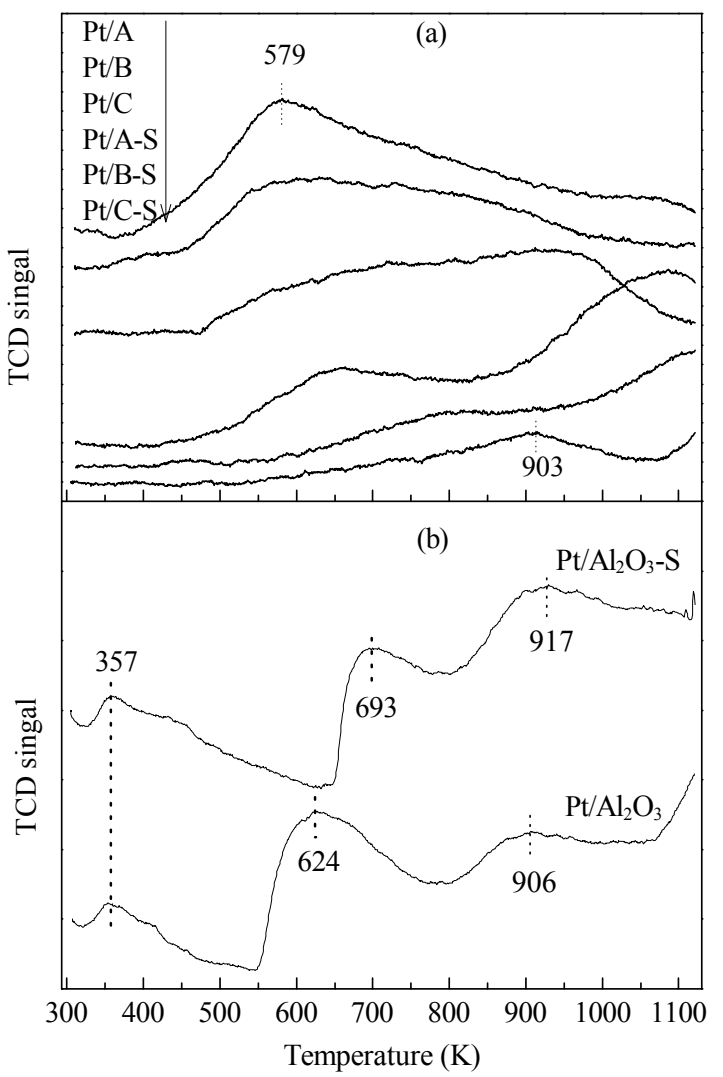

Fig. 5. CO-TPD profiles of the $\mathrm{Pt} / \mathrm{CeO}_{2}-\mathrm{ZrO}_{2}-\mathrm{La}_{2} \mathrm{O}_{3}$ (a) and $\mathrm{Pt} / \mathrm{Al}_{2} \mathrm{O}_{3}$ (b) catalysts before and after sulfation.

Table 2 Characteristic parameters from XPS spectra of non-sulfated and sulfated $\mathrm{Pt} / \mathrm{CeO}_{2}-\mathrm{ZrO}_{2}-\mathrm{La}_{2} \mathrm{O}_{3}$ catalysts

\begin{tabular}{|c|c|c|c|c|c|c|c|}
\hline \multirow{2}{*}{ Sample } & \multicolumn{5}{|c|}{ Binding energy $(\mathrm{eV})$} & \multicolumn{2}{|c|}{$\mathrm{Ce} / \mathrm{Zr}$ atomic ratio } \\
\hline & $\mathrm{O} 1 s$ & $\mathrm{Zr} 3 d_{5 / 2}$ & $\mathrm{Ce} 3 d_{5 / 2}$ & Pt $4 f_{7 / 2}$ & $\mathrm{~S} 2 p_{3 / 2}$ & Theoretical & Experimental \\
\hline $\mathrm{Pt} / \mathrm{A}$ & $528.8,530.8$ & 181.5 & 881.3 & 72.4 & - & 1.25 & 0.33 \\
\hline $\mathrm{Pt} / \mathrm{A}-\mathrm{S}$ & $529.5,531.7,532.6$ & 182.1 & 882.1 & 72.9 & 168.7 & 1.25 & 0.28 \\
\hline $\mathrm{Pt} / \mathrm{B}$ & $528.8,530.9$ & 181.5 & 881.6 & 72.5 & - & 1.25 & 0.57 \\
\hline $\mathrm{Pt} / \mathrm{B}-\mathrm{S}$ & $529.3,531.6,533.8$ & 181.8 & 882.2 & 72.9 & 168.9 & 1.25 & 0.66 \\
\hline $\mathrm{Pt} / \mathrm{C}$ & $529.1,531.1$ & 181.6 & 881.9 & 72.3 & - & 1.25 & 0.37 \\
\hline $\mathrm{Pt} / \mathrm{C}-\mathrm{S}$ & $529.6,531.6,533.6$ & 182.1 & 882.2 & 72.8 & 168.9 & 1.25 & 0.31 \\
\hline
\end{tabular}


while the second desorption peak increased in intensity in the opposite order. The two broad peaks of the three $\mathrm{Pt} / \mathrm{CeO}_{2}-\mathrm{ZrO}_{2}-\mathrm{La}_{2} \mathrm{O}_{3}$ catalysts were ascribed to $\mathrm{CO}$ adsorbed on different $\mathrm{Pt}$ sites or partially on $\mathrm{CeO}_{x}$. This assignment was based on the $\mathrm{CO}$ desorption temperatures being comparable to those of the reference catalyst $\mathrm{Pt} / \mathrm{Al}_{2} \mathrm{O}_{3}$ (Fig. 5(b)) where there were two desorption peaks at 624 and $906 \mathrm{~K}$. For $\mathrm{Pt} / \mathrm{Al}_{2} \mathrm{O}_{3}-\mathrm{S}$, the $\mathrm{CO}$ desorption temperature was clearly increased by sulfur poisoning. This likely resulted from the agglomeration of $\mathrm{Pt}$ atoms or that the $\mathrm{Al}_{2}\left(\mathrm{SO}_{4}\right)_{3}$ formed partially covered Pt particles causing the increase of the $\mathrm{CO}$ desorption temperature.

Table 1 shows that the dispersion of $\mathrm{Pt}$ on $\mathrm{CeO}_{2}-\mathrm{ZrO}_{2}$ $\mathrm{La}_{2} \mathrm{O}_{3}$ decreased in the order of $\mathrm{Pt} / \mathrm{A}>\mathrm{Pt} / \mathrm{B}>\mathrm{Pt} / \mathrm{C}$. This was the same as with the catalytic activity. After sulfiding, the CO-TPD profiles were two completely separated desorption peaks at low and high temperatures. The intensity of the $\mathrm{CO}$ desorption peak at the low temperature for the sulfated catalysts was drastically reduced, indicating that the amount of $\mathrm{CO}$ adsorbed on Pt sites decreased due to the poisoning of the Pt surface by sulfur. Moreover, the desorption temperature of $\mathrm{CO}$ adsorbed on Pt increased in the order of $\mathrm{Pt} / \mathrm{A}-\mathrm{S}<\mathrm{Pt} / \mathrm{B}-\mathrm{S}<\mathrm{Pt} / \mathrm{C}-\mathrm{S}$, while the intensity of the $\mathrm{CO}$ desorption peak decreased in the order of Pt/A-S $>$ $\mathrm{Pt} / \mathrm{B}-\mathrm{S}>\mathrm{Pt} / \mathrm{C}-\mathrm{S}$.

The TPR results shown in Fig. 6 gave information on the desulfurization characteristics of Pt/A-S, Pt/B-S, Pt/C-S, and $\mathrm{Pt} / \mathrm{Al}_{2} \mathrm{O}_{3}-\mathrm{S}$. No $\mathrm{H}_{2} \mathrm{~S}$ desorption was observed from $\mathrm{Pt} / \mathrm{Al}_{2} \mathrm{O}_{3}-\mathrm{S}$ in the temperature range of 563 to $900 \mathrm{~K}$. This, together with the XRF analysis result, indicated that the sulfur bonded to the $\mathrm{Pt}$ sites was irreducible. Compared with the peak intensity of the $\mathrm{H}_{2} \mathrm{~S}$ fragment of the $\mathrm{Pt} / \mathrm{CeO}_{2}$ $\mathrm{ZrO}_{2}-\mathrm{La}_{2} \mathrm{O}_{3}$ catalysts, one can find that the Pt/A-S sample contained the least amount of reducible $\mathrm{SO}_{4}{ }^{2-}$. This may be attributed to the different surface $\mathrm{Ce} / \mathrm{Zr}$ ratios. Because of

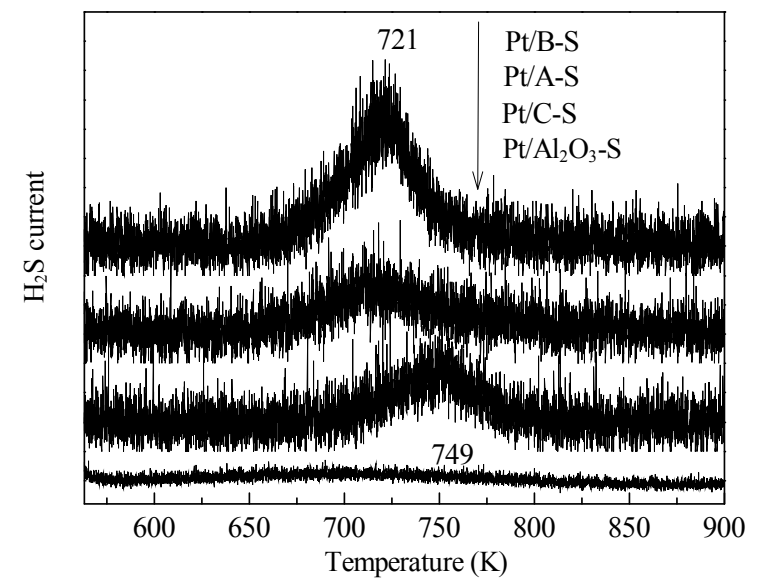

Fig. 6. TPR profiles of the sulfated $\mathrm{Pt} / \mathrm{CeO}_{2}-\mathrm{ZrO}_{2}-\mathrm{La}_{2} \mathrm{O}_{3}$ and $\mathrm{Pt} / \mathrm{Al}_{2} \mathrm{O}_{3}$ catalysts. the strong surface basicity and the unique feature of the storage and release oxygen of $\mathrm{CeO}_{2}$, it was more active in the adsorption and oxidation of the acidic $\mathrm{SO}_{2}$ as compared to $\mathrm{ZrO}_{2}$. Thus, a large $\mathrm{Ce} / \mathrm{Zr}$ ratio indicated more storage capacity of sulfur. The results of the catalytic activity evaluation showed that the regeneration treatment for the $\mathrm{Pt} / \mathrm{CeO}_{2}-\mathrm{ZrO}_{2}-\mathrm{La}_{2} \mathrm{O}_{3}$ samples improved the catalytic activity for both $\mathrm{CO}$ and $\mathrm{C}_{3} \mathrm{H}_{6}$ oxidation. This suggested that the reducible sulfur species bonding with the support was not the key factor deactivating the catalyst. Considering that the reduction regeneration significantly increased the light-off temperature of $\mathrm{CO}$ and $\mathrm{C}_{3} \mathrm{H}_{6}$ oxidation over the $\mathrm{Pt} / \mathrm{Al}_{2} \mathrm{O}_{3}-\mathrm{S}$ sample, which did not have reducible sulfur species, one can conclude that the poisoning of the Pt surface was mainly responsible for the deactivation of the sulfated $\mathrm{Pt} / \mathrm{CeO}_{2}$ $\mathrm{ZrO}_{2}-\mathrm{La}_{2} \mathrm{O}_{3}$ catalysts. Moreover, since the sulfur poisoning caused a textural change of the $\mathrm{Pt} / \mathrm{CeO}_{2}-\mathrm{ZrO}_{2}-\mathrm{La}_{2} \mathrm{O}_{3}$ catalysts, a small part of the Pt particles was possibly buried into the bulk of the $\mathrm{CeO}_{2}-\mathrm{ZrO}_{2}-\mathrm{La}_{2} \mathrm{O}_{3}$ support. This may be one factor causing the deactivation.

\section{Conclusions}

The synthesis procedure affected $\mathrm{Pt} / \mathrm{CeO}_{2}-\mathrm{ZrO}_{2}-\mathrm{La}_{2} \mathrm{O}_{3}$ catalysts with the same composition and gave significant differences in structure, texture, sulfurization-desulfization behavior, and catalytic behavior. The $\mathrm{Pt} / \mathrm{CeO}_{2}-\mathrm{ZrO}_{2}-\mathrm{La}_{2} \mathrm{O}_{3}$ catalyst with the larger surface $\mathrm{Ce} / \mathrm{Zr}$ ratio had more sulfur poisoning, and consequently a higher light-off temperature for the catalytic removal of pollutants in simulated diesel exhaust gas. The deactivation was mainly due to the poisoning of Pt surface by sulfur. The $\mathrm{CeO}_{2}-\mathrm{ZrO}_{2}-\mathrm{La}_{2} \mathrm{O}_{3}$ oxide with a $\mathrm{Zr}$-rich surface gave a good dispersion of $\mathrm{Pt}$, and hence excellent catalytic activity and sulfur tolerance.

\section{References}

1 张桂臻, 韩丽艳, 赵震, 刘坚, 段爱军, 姜桂元. 现代化工 (Zhang G Zh, Han L Y, Zhao Zh, Liu J, Duan A J, Jiang G Y. Mod Chem Ind), 2008, 28(1): 35

2 Agarwal A K. Prog Energy Combust Sci, 2007, 33: 233

3 Hosoya M, Shimoda M. Appl Catal B, 1996, 10: 83

4 Farrauto R J, Voss K E. Appl Catal B, 1996, $10: 29$

5 Stein H J. Appl Catal B, 1996, 10: 69

6 Liu J A, Xu J, Zhao Zh, Duan A J, Jiang G Y, Jing Y N. J Environ Sci (China), 2010, 22: 1104

7 Haneda M, Houshito O, Takagi H, Shinoda K, Nakahara Y, Hiroe K, Fujitani T, Hamada H. Top Catal, 2009, 52: 1868

8 Kim J R, Myeong W J, Ihm S K. J Catal, 2009, 263: 123

9 Haneda M, Shinoda K, Nagane A, Houshito O, Takagi H, Nakahara Y, Hiroe K, Fujitani T, Hamada H. J Catal, 2008, 259: 223 
10 Atribak I, Bueno-López A, García-García A. J Catal, 2008, 259: 123

11 Kolli T, Huuhtanen M, Hallikainen A, Kallinen K, Keiski R L. Catal Lett, 2009, 127: 49

12 Kolli T, Kanerva T, Lappalainen P, Huuhtanen M, Vippola M, Kinnunen T, Kallinen K, Lepistö T, Lahtinen J, Keiski R L. Top Catal, 2009, 52: 2025

13 Kolli T, Kanerva T, Huuhtanen M, Vippola M, Kallinen K, Kinnunen T, Lepistö T, Lahtinen J, Keiski R L. Catal Today, 2010, 154: 303

14 Trovarelli A. Catal Rev-Sci Eng, 1996, 38: 439

15 Aneggi E, de Leitenburg C, Dolcetti G, Trovarelli A. Catal Today, 2006, 114: 40

16 Setiabudi A, Chen J, Mul G, Makkee M, Moulijn J A. Appl Catal B, 2004, 51; 9

17 Bazin P, Saur O, Meunier F C, Daturi M, Lavalley J C, Le Govic A M, Harlé V, Blanchard G. Appl Catal B, 2009, 90: 368
18 Rohart E, Bellière-Baca V, Yokota K, Harlé V, Pitois C. Top Catal, 2007, 42-43: 71

19 Si R, Zhang Y W, Wang L M, Li S J, Lin B X, Chu W S, Wu Z Y, Yan C H. J Phys Chem C, 2007, 111: 787

20 Zhong F L, Xiao Y H, Weng X M, Wei K M, Cai G H, Zheng Y, Zheng Q. Catal Lett, 2009, 133: 125

21 Joly V L J, Joy P A, Date S K. J Magn Magn Mater, 2002, 247: 316

22 郭大为. 石油学报 (石油加工)(Guo D W. Acta Petrol Sin (Petrol Process Sect)), 2010, 26: 235

23 Luo T, Gorte R J. Appl Catal B, 2004, 53: 77

24 Waqif M, Bazin P, Saur O, Lavalley J C, Blanchard G, Touret O. Appl Catal B, 1997, 11: 193

25 Huang M H, Li L R, Guo Y L. J Soild State Electrochem, 2009, 13: 1403

26 Corro G, Fierro J L G, Odilon V C. Catal Commun, 2003, 4: 371 